\title{
Tissue-specific induction of $17 \beta$-hydroxysteroid dehydrogenase type IV by peroxisome proliferator chemicals is dependent on the peroxisome proliferator-activated receptor $\alpha$
}

\author{
L-Q Fan, R C Cattley and J C Corton \\ Chemical Industry Institute of Toxicology, PO Box 12137, Research Triangle Park, North Carolina 27709, USA \\ (Requests for offprints should be addressed to C Corton, CIIT, 6 Davis Drive, PO Box 12137, Research Triangle Park, North Carolina 27709, USA)
}

\begin{abstract}
The $17 \beta$-hydroxysteroid dehydrogenase (17 $\beta$-HSD) family of proteins regulates the levels of the active $17 \beta-$ hydroxy forms of sex steroids. The expression of $17 \beta-H S D$ type IV is induced by peroxisome proliferator chemicals (PPC) in rat liver. In order to characterize more generally the impact of PPC on $17 \beta-$ HSD expression, we determined (1) if expression of other members of the $17 \beta-\mathrm{HSD}$ family was coordinately induced by PPC exposure, (2) the tissues in which $17 \beta-\mathrm{HSD}$ was induced by PPC, and (3) whether the induction of $17 \beta-$ HSD by PPC was dependent on the peroxisome proliferator-activated receptor $\alpha$ $(\operatorname{PPAR} \alpha)$, the central mediator of PPC effects in the mouse liver. The mRNA levels of $17 \beta-H S D$ I, II, and III were not altered in the liver, kidney, and testis or uterus of rats treated with PPC. The mRNA or $80 \mathrm{kDa}$ full-length protein levels of $17 \beta-H S D$ IV were strongly induced in
\end{abstract}

liver and kidney, but not induced in adrenals, brown fat, heart, testis, and uterus of rats treated with diverse PPC. In liver and kidneys from treated rats, additional proteins of $66 \mathrm{kDa}, 56 \mathrm{kDa}$, and $32 \mathrm{kDa}$ were also induced which reacted with the anti-17 $\beta$-HSD IV antibodies and were most likely proteolytic fragments of $17 \beta-H S D$ IV. Treatment of mice which lack a functional form of PPAR $\alpha$ with PPC, demonstrated that PPC-inducibility of $17 \beta-H S D$ IV mRNA or the $80 \mathrm{kDa}$ protein was dependent on PPAR $\alpha$ expression in liver and kidney. Our results demonstrate that $17 \beta-H S D$ IV is induced by PPC through a PPAR $\alpha-$ dependent mechanism and support the hypothesis that exposure to PPC leads to alterations in sex steroid metabolism.

Journal of Endocrinology (1998) 158, 237-246

\section{Introduction}

The $17 \beta$-hydroxysteroid dehydrogenases $(17 \beta$-HSD) are an important enzyme family which catalyze the interconversion of inactive (or less active) 17-keto and active $17 \beta$-hydroxy forms of estrogen, androgen, and progesterone (reviewed in Andersson \& Moghrabi 1997). Six types of $17 \beta-$ HSDs have been identified. $17 \beta-H S D$ type I, originally cloned from a human placental library is also expressed in the ovary and mammary gland (Martel et al. 1992, Ghersevich et al. 1994, Nokelaninen et al. 1996). The type II enzyme, cloned from prostatic and placental cDNA libraries, is expressed in many tissues including liver, small intestine, endometrium, kidney, pancreas and colon in humans (Casey et al. 1994, Akinola et al. 1996). The expression of $17 \beta-H S D$ type III is primarily restricted to testes in humans and mice (Geissler et al. 1994, Sha et al. 1997). The 17 $\beta$-HSD IV, originally cloned from porcine endometrium (Adamski et al. 1995) is broadly expressed in rodents and humans (Mustonen et al. 1997, Carstensen et al. 1996). A human type V isozyme is expressed in liver and skeletal muscle (Zhang et al. 1995).
A $17 \beta-H S D$ type VI was cloned from rat prostate and is also expressed in liver (Biswas \& Russell 1997). In keeping with their sex organ-specific expression, types I and III have been shown preferentially to catalyze the production of $17 \beta$-hydroxy forms of estrogen and androgen respectively (Luu-The et al. 1995). In general, types II, IV, and VI inactivate the sex steroids by catalyzing the production of the keto forms in peripheral tissues.

The type IV enzyme possesses a number of unique features compared with the other $17 \beta-H S D$ family members. First, $17 \beta-$ HSD IV is found primarily in peroxisomes (Markus et al. 1995) whereas the other 17 $\beta$-HSD family members are located either in microsomes or in cytosol (summarized in Andersson \& Moghrabi 1997). Secondly, $17 \beta-H S D$ IV is a multifunctional protein possessing separable $17 \beta$-hydroxysteroid/fatty acyl-CoA dehydrogenase, fatty acyl-CoA-hydratase and sterol transfer activities (Leenders et al. 1996). 17 $\beta$-HSD IV has also recently been found to be involved in degradation of branched chain fatty acids (Dieuaide-Noubhani et al. 1997a) and the side chain of cholesterol (Dieuaide-Noubhani et al. 1997b). Lastly, 17ß-HSD IV expression is stimulated by 
peroxisome proliferator chemicals in rat liver leading to the hypothesis that exposure to these chemicals could result in alteration of estrogen-dependent functions (Corton et al. 1996).

Peroxisome proliferator chemicals (PPC) are a large group of chemicals which include hypolipidemic drugs, plasticizers, and industrial solvents that induce hepatomegaly and hepatic peroxisome proliferation in rodents. Responses to PPC exposure are controlled by members of the nuclear receptor superfamily called peroxisome proliferator-activated receptors (PPAR). After binding PPC, these receptors heterodimerize with another member of the superfamily called retinoid $X$ receptor (RXR). The PPAR-RXR heterodimer binds to DNA sequences called peroxisome proliferator response elements found in responsive genes resulting in either transcriptional activation or down-regulation (reviewed in Lapinskas \& Corton 1998). Genes induced by PPAR include those that catalyze $\beta$ - and $\omega$-oxidation of fatty acids. Using a mouse strain which lacks a functional form of PPAR $\alpha$ (PPAR $\alpha-$ null mouse), Lee et al. (1995) demonstrated that most, if not all, of the effects induced by PPC in the liver are mediated by PPAR $\alpha$.

To characterize more generally the impact of PPC on $17 \beta-H S D$ expression, we determined if tissues important in metabolizing steroids were sensitive to the induction of $17 \beta-H S D$ family members by PPC. Furthermore, we evaluated the mechanism of the PPC-mediated induction of $17 \beta-\mathrm{HSD}$ by comparing inductive behavior in wild-type mice with mice which lack a functional PPAR $\alpha$.

\section{Materials and Methods}

\section{Animals}

These studies were conducted under federal guidelines for the use and care of laboratory animals and were approved by the Chemical Industry Institute of Toxicology Institution Animal Care and Use Committee. In the first three studies, F344 (CDF(F344)/CrlBR) rats, 6-8 weeks of age were obtained from the Charles River Breeding Laboratories, Inc. (Raleigh, NC, USA). Control and treated rats or mice were provided with $\mathrm{NIH}-07$ rodent chow (Ziegler Bros., Gardner, PA, USA) and deionized, filtered water ad libitum. Lighting was on a $12 \mathrm{~h}$ light: $12 \mathrm{~h}$ darkness cycle. In the first study, male and female F344 rats were fed rodent chow containing 500 parts per million (ppm) WY-14,643 (WY; ChemSyn Science Laboratories, Lenexa, KS, USA), 8000 ppm gemfibrozil (GEM, Sigma Chemical Co., St Louis, MO, USA) or 20000 ppm di-n-butyl phthalate (DBP, Aldrich Chemical Co., Milwaukee, WI, USA) for 13 weeks. In the second study, male and female F344 rats were given gavage doses of either vehicle (methylcellulose), WY $(50 \mathrm{mg} / \mathrm{kg}$ body weight), or di-(2-ethylhexyl) phthalate (DEHP; $2000 \mathrm{mg} /$ kg body weight) in methylcellulose each day for three days. In the third study, male F344 rats were fed rodent chow containing 1.2\% DEHP, clofibric acid (CA; 0.5\%) or WY $(0 \cdot 1 \%)$, for 22 weeks. In the fourth study, male SV129 wild-type, (Taconic, Germantown, NY, USA) and SV129 PPAR $\alpha$-null mice (Lee et al. 1995) 6-8 weeks of age were fed WY $(0 \cdot 1 \%)$ or DEHP $(0 \cdot 6 \%)$ for three weeks. At the designated time following treatment, animals were deeply anesthetized by pentobarbital injection and killed by exsanguination. The tissues were removed, rinsed with isotonic saline, snap-frozen in liquid nitrogen and stored at $-70{ }^{\circ} \mathrm{C}$ until analysis.

\section{Hepatocyte isolation and cell culture}

For preparation of primary hepatocytes, adult male Fischer F344 rats (approximate weight 200-250 g), were obtained from Charles River Breeding Laboratories. The animals were maintained under conditions of constant temperature and humidity and allowed rodent chow and water ad libitum. Hepatocytes were isolated by nonrecirculating collagenase perfusion through the portal vein of pentobarbital-anesthetized rats according to the method of Kedderis et al. (1988). A thin coat of Matrigel (Becton Dickinson, Bedford, MA, USA) was applied to $100 \mathrm{~mm}$ diameter plastic culture dishes and allowed to gel at room temperature. Cells, $2.6 \times 10^{6}$ per $100 \mathrm{~mm}$ plate with viability greater than $80 \%$ as determined by trypan blue exclusion, were plated in $3 \mathrm{ml}$ modified Waymouth media containing insulin $(0 \cdot 2 \mu \mathrm{g} / \mathrm{ml})$ as the only hormone. Cultures were maintained in an incubator at $37^{\circ} \mathrm{C}$ in an atmosphere containing 5\% $\mathrm{CO}_{2}$. Medium was replaced daily, commencing $24 \mathrm{~h}$ after the cells were plated. Cells were cultured for five days before treatment as described (Chen et al. 1995). Dimethyl sulfoxide or WY at the indicated concentrations was added, and the cells were incubated for $48 \mathrm{~h}$ changing the media after $24 \mathrm{~h}$. Media were aspirated from culture dishes and replaced with $3 \mathrm{ml}$ ice-cold, phosphate-buffered saline, with $5 \mathrm{mM}$ ethylene-

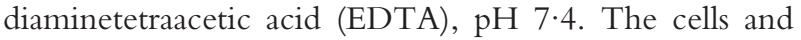
Matrigel were transferred to $15 \mathrm{ml}$ capped plastic tubes and then allowed to stand on ice for $45 \mathrm{~min}$ to dissolve the Matrigel. Cells were then collected by centrifugation at $800 \boldsymbol{g}$ for $5 \mathrm{~min}$ and lyzed. Extracts were used for analysis of protein expression.

\section{Northern blot analysis}

Total RNA was isolated by a modification of the guanidinium isothiocyanate method using RNAzol B according to the manufacturer's instructions (Tel-Test, Friendswood, TX, USA). Twenty micrograms denatured total RNA was separated on $1.0 \%$ formaldehyde-agarose gels and transferred to Hybond-N nylon membranes in $20 \times$ standard saline citrate buffer. The RNA was fixed by UV cross linking using a Stratalinker UV crosslinker (Stratagene, La 
Jolla, CA, USA). The membrane was prehybridized with Hybrisol I (Oncor Inc., Gaithersburg, MD, USA) for $4 \mathrm{~h}$ at $42{ }^{\circ} \mathrm{C}$, followed by hybridization overnight. The $1.4 \mathrm{~kb}$ EcoRI fragment encoding the rat $17 \beta-H S D$ I cDNA and the $1.3 \mathrm{~kb}$ EcoRI fragment encoding the rat $17 \beta-$ HSD II were generated from the plasmids kindly provided by Dr Hellevi Peltoketo (University of Oulu, Oulu, Finland). The $740 \mathrm{bp}$ SacI-KpnI fragment encoding the mouse $17 \beta-H S D$ III was generated from a plasmid kindly provided by Dr Paul J Baker (University of Glasgow Veterinary School, Glasgow, UK). The rat full-length $2.4 \mathrm{~kb} 17 \beta$-HSD type IV cDNA probe was generated by PCR using M13 forward and M13 reverse primers and pBluescript IISK plasmid encoding 17 $\beta$-HSD IV (Corton et al. 1996). The $\beta$-actin cDNA was obtained from Oncor Inc. $\beta$-Actin was used as a loading control since the level does not change after short-term exposure to WY (Goldsworthy et al. 1993). The probes for Northern analysis were labeled with $\left[\alpha-{ }^{32} \mathrm{P}\right] \mathrm{dCTP}$ (Amersham, Cleveland, OH, USA) using the random-primer DNA labeling kit according to the manufacturer's instructions (Stratagene). After washing, the filter was exposed to BioMax X-ray film (Eastman Kodak Co.) at $-70^{\circ} \mathrm{C}$ with intensifying screen. The size of mRNA was determined by comparing mobility relative to an RNA ladder (GIBCO/BRL, Gaithersburg, MD, USA).

\section{Western blot analysis}

Whole-cell protein extracts $(100 \mu \mathrm{g}$ total protein), made according to Wilcke and Alexson (1994), were denatured and size-separated by $12.5 \%$ SDS-PAGE. Proteins were transferred to nitrocellulose (Stratagene) and visualized by Ponceau Red to confirm transfer. The membrane was washed with phosphate-buffered saline-Tween (PBST). The membranes were blocked by incubating in PBST containing 5\% non-fat dry milk. Immunoreactivity was detected by incubation with primary antibody followed by horseradish peroxidase conjugated goat-anti-rabbit IgG (Amersham) as secondary antibody. The reaction was detected by enhanced chemiluminescence (SuperSignal, Pierce Chemical Co., Rockford, IL, USA). The sizes of the reactive immunoproteins were estimated by the gel fragment sizer software (DogStar Software, Bloomington, IN, USA) by comparison to the mobility of protein standards (Rainbow marker; Amersham). Autoradiograms for Northern blots and Western blots were densitometrically scanned using Image-1 image analysis system (Universal Imaging Corporation, West Chester, PA, USA) and NIH Image 1.54 software. The $17 \beta-H S D$ IV antibodies from two sources (Jerzy Adamski, GSF Research Center, Neuherberg, Germany and Takashi Hashimoto, Shinshu University School of Medicine, Matsumoto, Nagano, Japan) gave the same results. Antibodies obtained from J Adamski were prepared against porcine 17 $\beta$-HSD IV but they crossreact with human, rat and mouse tissues. The anti-acyl-CoA oxidase (ACO) antibody was from Stefan Alexson (Huddinge University Hospital, Huddinge, Sweden).

\section{Results}

Alteration of $17 \beta-H S D m R N A$ expression after exposure to PPC

The mRNA levels of $17 \beta-H S D$ I, $17 \beta-H S D$ II, $17 \beta-H S D$ III and $17 \beta-H S D$ IV were determined by Northern blot analysis in rats treated in the diet for 13 weeks with three PPC (WY, GEM, and DBP). The type I mRNA was detected in uterus as a $1.5 \mathrm{~kb}$ mRNA but not in liver, kidney, or testis from control rats. The $17 \beta-H S D$ II mRNA $(1.6 \mathrm{~kb})$ was expressed to high levels in liver and moderate levels in kidney in control rats. The type III mRNA was detected as a $1.4 \mathrm{~kb}$ mRNA in testis but not in liver, kidney or uterus from control rats. The pattern of expression of the 17 $\beta-$ HSD I, II, and III is consistent with earlier studies (Mustonen et al. 1997 and references therein). After PPC treatment the abundance of types I, II, or III was not altered in any of the tissues examined (data not shown). In contrast the $2 \cdot 8 \mathrm{~kb} 17 \beta$-HSD IV mRNA levels were increased ( $\sim 3-4$ fold) in rats fed WY, GEM and DBP compared with control rats (Fig. 1A). In the kidneys of rats fed PPC, there was no significant induction of $17 \beta-H S D$ IV mRNA (Fig. 1B). Weak constitutive expression of $17 \beta-\mathrm{HSD}$ IV mRNA could be detected in heart and testis, but no changes in levels were observed after PPC exposure (data not shown). Thus, the increases in $17 \beta-H S D$ mRNA levels were specific for the type IV gene.

\section{Alterations in $17 \beta-H S D$ IV protein levels after exposure to PPC}

In parallel with the analysis of $17 \beta-H S D$ mRNA expression, we analyzed the $17 \beta-$ HSD IV protein levels after a 13 week exposure to PPC in whole-cell extracts by Western blot analysis from the same tissues used for mRNA expression. In the absence of treatment we could detect only weak expression of the $80 \mathrm{kDa}$ full-length $17 \beta-H S D$ IV protein (Fig. 2A). The full-length 17 $\beta$-HSD IV protein was strongly induced after treatment by GEM (95-fold) and induced to lesser extents by WY (9-fold) and DBP (4-fold). The preferential induction by GEM under these conditions is in contrast to the almost equal induction of the mRNA by the three PPC. As noted before, posttranscriptional differences in protein translation efficiency or protein stability could be responsible (Corton et al. 1996). Immunoreactive proteins of $66 \mathrm{kDa}, 56 \mathrm{kDa}$, $42 \mathrm{kDa}$, and $32 \mathrm{kDa}$ were also strongly induced by GEM. After WY and DBP treatment, the $66 \mathrm{kDa}$ and $56 \mathrm{kDa}$ proteins were induced but to lesser extents. These changes 
A
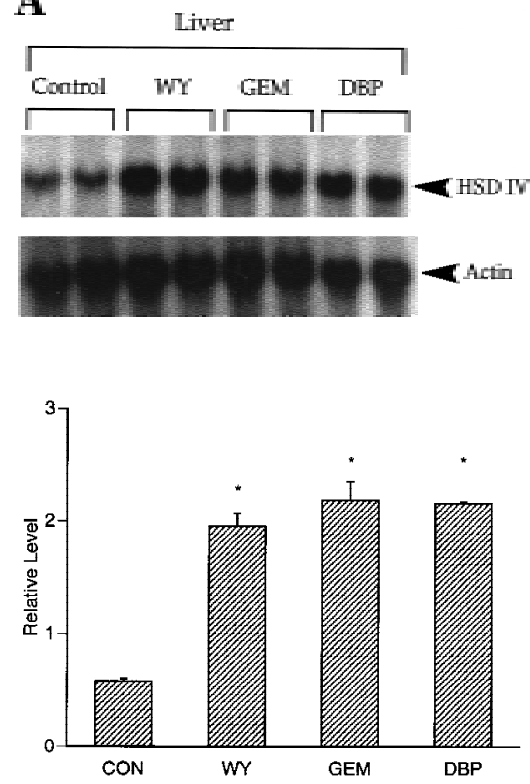

B
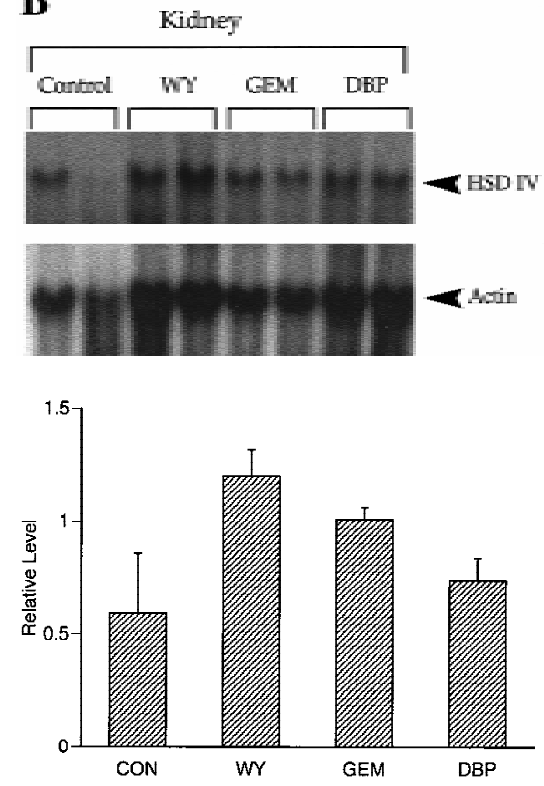

Figure 1 Expression of $17 \beta$-HSD IV mRNA after PPC exposure. Northern blot analysis of 17ß-HSD IV mRNA in liver (A, upper) and kidney (B, upper) from control and treated rats. Total RNA was isolated from F344 male rats fed a control diet (Control) or diets which contained 500 ppm WY, 8000 ppm GEM, or 20000 ppm DBP for 13 weeks. Total RNA was separated on formaldehyde-agarose gels, transferred to nylon membranes and probed with either the full-length rat $17 \beta$-HSD IV cDNA or a fragment of $\beta$-actin. The autoradiograms were densitometrically scanned and $17 \beta$-HSD IV expression in liver (A, lower) and kidney (B, lower) was normalized to $\beta$-actin expression. The histograms show the mean induction (mean \pm S.D.) from two different samples. ${ }^{*} P<0 \cdot 05$ compared with control.

were similar to those observed earlier in liver after PPC treatment (Corton et al. 1996) using a different antibody to $17 \beta-H S D$ IV.

In parallel with the increases in $17 \beta-H S D$ IV protein levels in rat liver after PPC treatment, we observed increases in the expression of ACO protein (Fig. 2A, bottom). Interestingly, the pattern of induction of different forms of the ACO protein was unique to the compound. WY induced expression of two forms of ACO to approximately equal extents: ACO-A, the $72 \mathrm{kDa}$ full-length ACO protein and ACO-B, a $56 \mathrm{kDa}$ form which results from proteolytic processing of ACO-A. After GEM treatment, most of the induced ACO protein was found to be ACO-B with little ACO-A observed. Treatment with DBP resulted in weak induction of ACO-B only.

In control kidneys the full-length $17 \beta-H S D$ IV protein plus proteins of $42 \mathrm{kDa}$ and $32 \mathrm{kDa}$ (bands 3 and 4 respectively) were observed. The 42 and $32 \mathrm{kDa}$ proteins were indistinguishable in size to proteins induced after GEM treatment in liver. After exposure to GEM, the $80 \mathrm{kDa}$ protein was induced 9-fold in rat kidneys. WY and DBP also induced the $80 \mathrm{kDa}$ protein albeit to lesser extents (4-fold and 3-fold respectively). Immunoreactive proteins of $66 \mathrm{kDa}, 56 \mathrm{kDa}$, and $32 \mathrm{kDa}$ were also strongly induced by GEM following the pattern observed in the liver of GEM-treated rats. Slight induction of the $56 \mathrm{kDa}$ protein was seen in kidneys after WY or DBP treatment.
In contrast to liver, the expression of the $42 \mathrm{kDa}$ protein did not change after exposure to any PPC.

ACO protein was also differentially induced by PPC in the kidneys. Increases in the levels of ACO-A and ACO-B were detected after WY or GEM treatment (Fig. 2B). Little, if any, increase in ACO was detected after DBP treatment.

In a separate feeding study rats were treated in the diet for 22 weeks with PPC (WY, CA and DEHP), and $17 \beta-H S D$ IV expression was analyzed in interscapular brown fat and adrenals. In the brown fat from control rats, expression of full-length 17 $\beta-H S D$ IV, and variable expression of the $42 \mathrm{kDa}$ fragment were detected (Fig. 2C). After exposure to CA or WY, slight induction of the full-length protein was detected (1.6-fold and 2.5-fold respectively) but was not statistically significant. Weak induction of the $56 \mathrm{kDa}$ and $32 \mathrm{kDa}$ fragments was also observed after WY treatment. WY was the strongest inducer of ACO-A and ACO-B in brown fat, with DEHP and CA treatment resulting in little, if any, induction.

In adrenals from control rats only the $42 \mathrm{kDa}$ fragment was expressed to appreciable levels (Fig. 2D). After PPC exposure no induction of $17 \beta-\mathrm{HSD}$ IV or any of the immunoreactive fragments was observed. However, we did observe that the expression of full-length protein was induced by CA in liver in the same feeding study (data not shown). Induction of ACO-A was observed in adrenals 


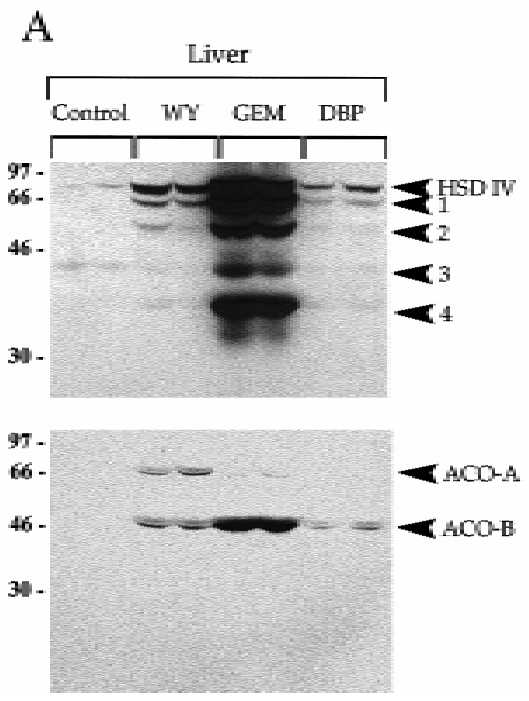

$\mathrm{C}$

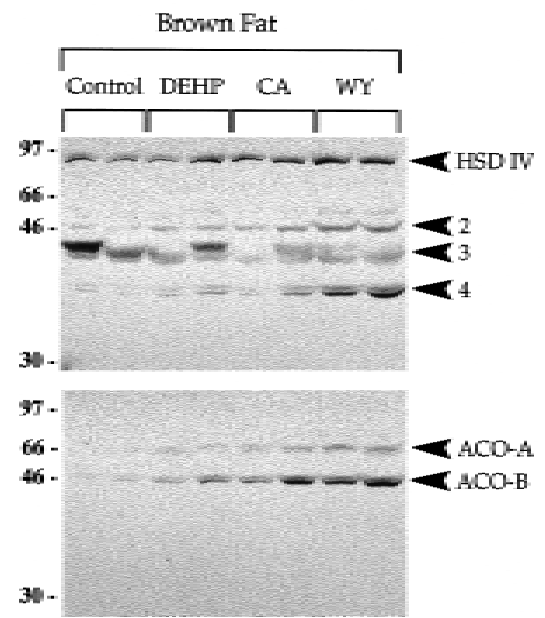

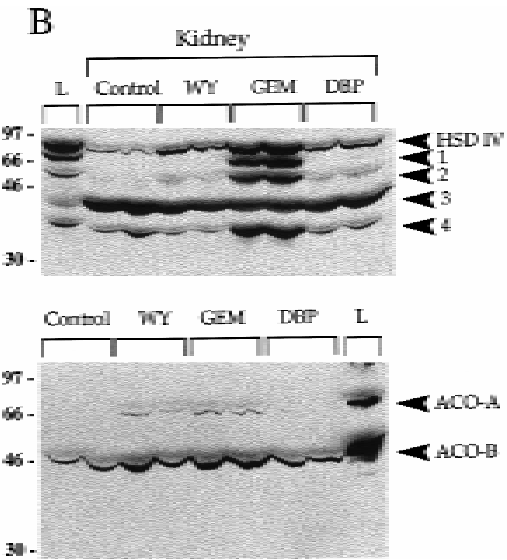

$\mathrm{D}$

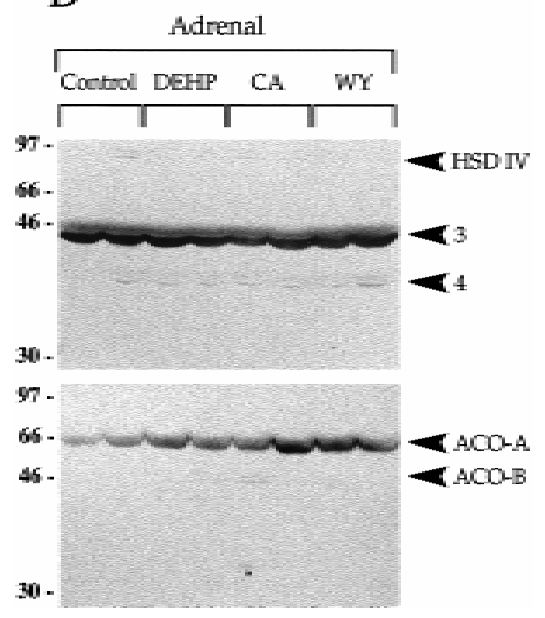

Figure 2 Expression of $17 \beta$-HSD IV protein after chronic PPC exposure. Western blot analysis of $17 \beta$-HSD IV protein in liver (A), kidney $(B)$, brown fat (C), and adrenal (D) from control and treated rats. Whole-cell liver or kidney protein extracts were made from the rats used in Fig. 1. Whole-cell brown fat or adrenal protein extracts were made from rats fed DEHP $(1 \cdot 2 \%)$, CA $(0 \cdot 5 \%)$ or WY $(0 \cdot 1 \%)$ in the diet for 22 weeks. Protein extracts of each sample $(100 \mu \mathrm{g})$ were separated by $12 \cdot 5 \%$ SDS-PAGE, transferred to nitrocellulose membranes and probed with antibodies against 17 $\beta$-HSD IV or ACO. In (B), protein extracts from livers of rats treated with 8000 ppm GEM for 13 weeks were run as a control (L). 17 $\beta$-HSD IV, position of the full-length $80 \mathrm{kDa} 17 \beta$-HSD IV protein; $1-4$, positions of immunoreactive proteins with molecular masses of 66, 56, 42 and $32 \mathrm{kDa}$ respectively. The position of ACO forms A and B which have molecular masses of 72 and $52 \mathrm{kDa}$ respectively are indicated. Numbers on the left are the position of molecular mass markers (kDa).

from rats treated with WY. Induction of ACO-B was not observed after any treatment.

To begin to determine how rapidly accumulation of the full length 17 $\beta-H S D$ IV and fragment changes after exposure, and to determine if sex-specific differences in induction exist, 17 $\beta$-HSD IV and ACO protein expression was also examined in the livers of male and female rats given a gavage dose of WY or DEHP each day for three days. As shown in Fig. 3, exposure to WY resulted in increased abundance of the full-length $17 \beta-$ HSD IV (3-fold in males and 2-fold in females). Treatment with DEHP did not appreciably alter the full-length $17 \beta-H S D$ IV expression. There was a high level constitutive expression of the 42 and $32 \mathrm{kDa}$ proteins that was not observed in earlier studies. Exposure to either WY or DEHP resulted in increased expression of ACO-B with WY inducing more than DEHP.

Next we determined if the PPC-induced expression could be reconstituted in vitro by examining the expression of $17 \beta-H S D$ IV in rat primary hepatocytes after a $48-h$ 


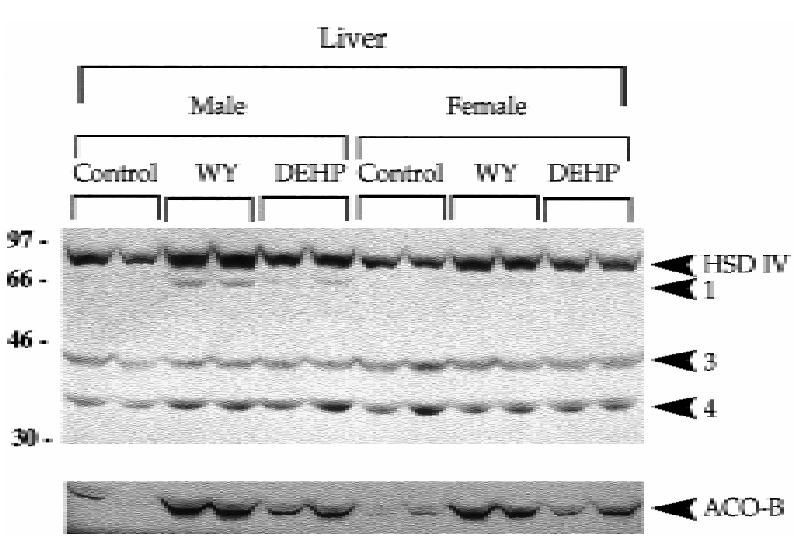

Figure 3 Expression of $17 \beta$-HSD IV protein after acute PPC exposure. Western blot analysis of $17 \beta-$ HSD IV protein from livers of male and female F344 rats given daily gavage doses of WY (50 mg/kg body weight) or DEHP (200 mg/kg body weight) for 3 days. Whole-cell protein extracts $(100 \mu \mathrm{g})$ were separated and analyzed as described in the legend to Fig. 2.

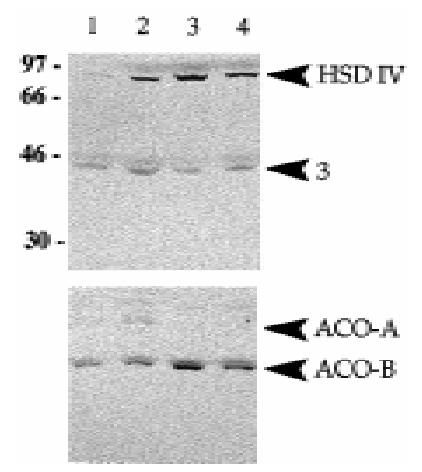

Figure 4 Increased expression of $17 \beta$-HSD IV protein by WY in vitro. Rat primary hepatocytes were treated with solvent control (lane 1), and $100 \mu \mathrm{M}$ (lane 2), $200 \mu \mathrm{M}$ (lane 3) or $400 \mu \mathrm{M}$ (lane 4) $\mathrm{WY}$ for $48 \mathrm{~h}$. Protein extracts were analyzed by Western blot for expression of $17 \beta$-HSD IV and ACO as described in the legend to Fig. 2.

treatment with different doses of WY. As shown in Fig. 4, expression of the full-length $17 \beta-H S D$ IV but not the immunoreactive fragments and ACO-B increased after WY exposure in a dose-dependent manner increasing to maximal levels at $200 \mu \mathrm{M}$ WY. At $400 \mu \mathrm{M}$ WY the expression of both proteins was detectably decreased. Inhibition of PPC-inducible gene expression at high doses of PPC has been observed before (Rocos \& Ledwith 1997 and references therein).

\section{Dependence of $17 \beta-H S D$ IV induction by PPC on expression of PPARa}

To determine if PPAR $\alpha$ is important in the induction of $17 \beta$-HSD IV after PPC exposure, we examined mRNA and protein expression in tissues from wild-type mice and mice which lack a functional form of PPAR $\alpha$ (PPAR $\alpha-$ null mice). Wild-type and PPAR $\alpha$-null mice were fed a control diet or diets containing $0.1 \%$ WY or $0.6 \%$ DEHP for 3 weeks. As shown in Fig. 5A, expression of the $2.5 \mathrm{~kb}$ $17 \beta-H S D$ IV mRNA was increased in the livers of wild-type mice after treatment with WY or DEHP (3-fold and 4-fold respectively). This induction was abolished in PPAR $\alpha$-null mice treated with either WY or DEHP. In kidneys from wild-type mice, the levels of $17 \beta-H S D$ IV mRNA increased after WY and DEHP treatments $(2 \cdot 2-$ fold and 2.0-fold respectively) (Fig. 5B). The increase was abolished in the PPAR $\alpha$-null mice. In contrast to the increases in $17 \beta$-HSD IV mRNA levels after treatment in liver and kidney, the expression of $17 \beta-$ HSD IV did not change after exposure in testis (Fig. 5C) or heart (data not shown) from wild-type or PPAR $\alpha$-null mice.

The expression of the $17 \beta-H S D$ IV protein was also examined in wild-type and PPAR $\alpha$-null mouse tissues. In livers of both mouse types, expression of the 17 $\beta$-HSD IV $80 \mathrm{kDa}$ protein and the $42 \mathrm{kDa}$ immunoreactive protein was detected in the absence of exposure. In wild-type mice, the $80 \mathrm{kDa} 17 \beta-\mathrm{HSD}$ IV protein was induced after WY or DEHP exposure (7-fold and 4-fold respectively) (Fig. 6A). Immunoreactive proteins of $66 \mathrm{kDa}$ and $56 \mathrm{kDa}$ were also induced by WY or DEHP in wild-type mice. The $42 \mathrm{kDa}$ fragment was not induced by PPC treatment. No induction of the $80 \mathrm{kDa}$ protein or any of the immunoreactive proteins was observed in $\operatorname{PPAR} \alpha$-null mice after WY or DEHP exposure. ACO-A and ACO-B proteins were strongly induced in wild-type but not PPAR $\alpha$-null mice after WY or DEHP treatment as demonstrated previously for ACO mRNA (Lee et al. 1995).

The dependence of $17 \beta-H S D$ IV inducibility on $\operatorname{PPAR} \alpha$ expression was also examined in whole-cell extracts from kidneys. Both mouse strains constitutively expressed the $42 \mathrm{kDa}$ protein in the absence of exposure (Fig. 6B). Weak expression of the $32 \mathrm{kDa}$ fragment was also detected in both mouse strains. After exposure to WY or DEHP, the $80 \mathrm{kDa}$ full-length protein was induced in kidneys of wild-type mice (9-fold and 7-fold respectively). In the PPAR $\alpha$-null mice, no induction of the full-length $17 \beta-H S D$ IV or fragments was observed after exposure to WY or DEHP. Expression of ACO-A and ACO-B was increased after WY but not DEHP exposure in wild-type mice (Fig. 6B). Although little, if any, increase in ACO-B could be observed in the kidneys of PPAR $\alpha$-null mice after WY exposure, ACO-B was increased after DEHP treatment. This induction may be mediated by other PPAR isoforms which are expressed in the kidney (Braissant et al. 1996).

In testis both wild-type and PPAR $\alpha$-null mice lacked expression of the full-length protein but strongly expressed the $42 \mathrm{kDa}$ immunoreactive protein and a unique $38 \mathrm{kDa}$ immunoreactive protein (Fig. 6C). No changes in the expression of the full-length $17 \beta-\mathrm{HSD}$ IV, $17 \beta-H S D$ IV immunoreactive proteins or ACO were 


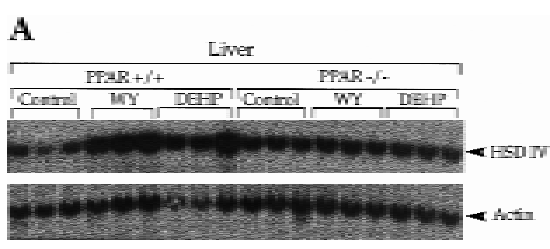

B

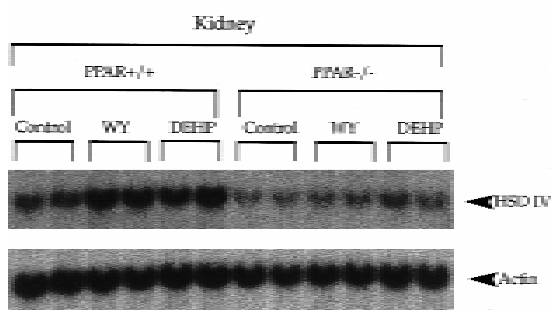

C

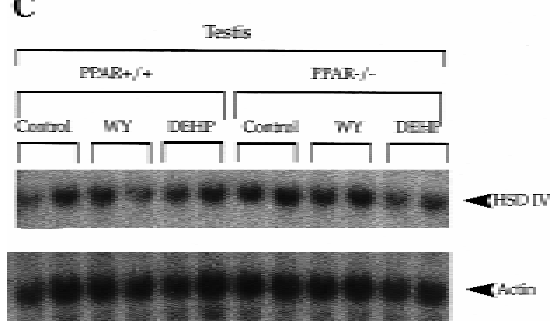

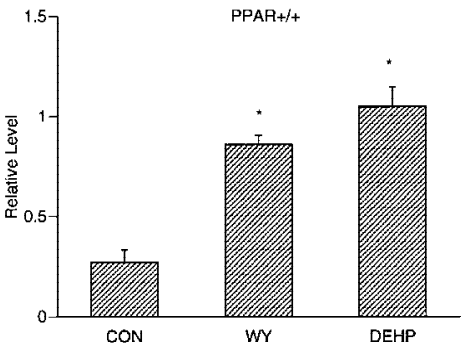
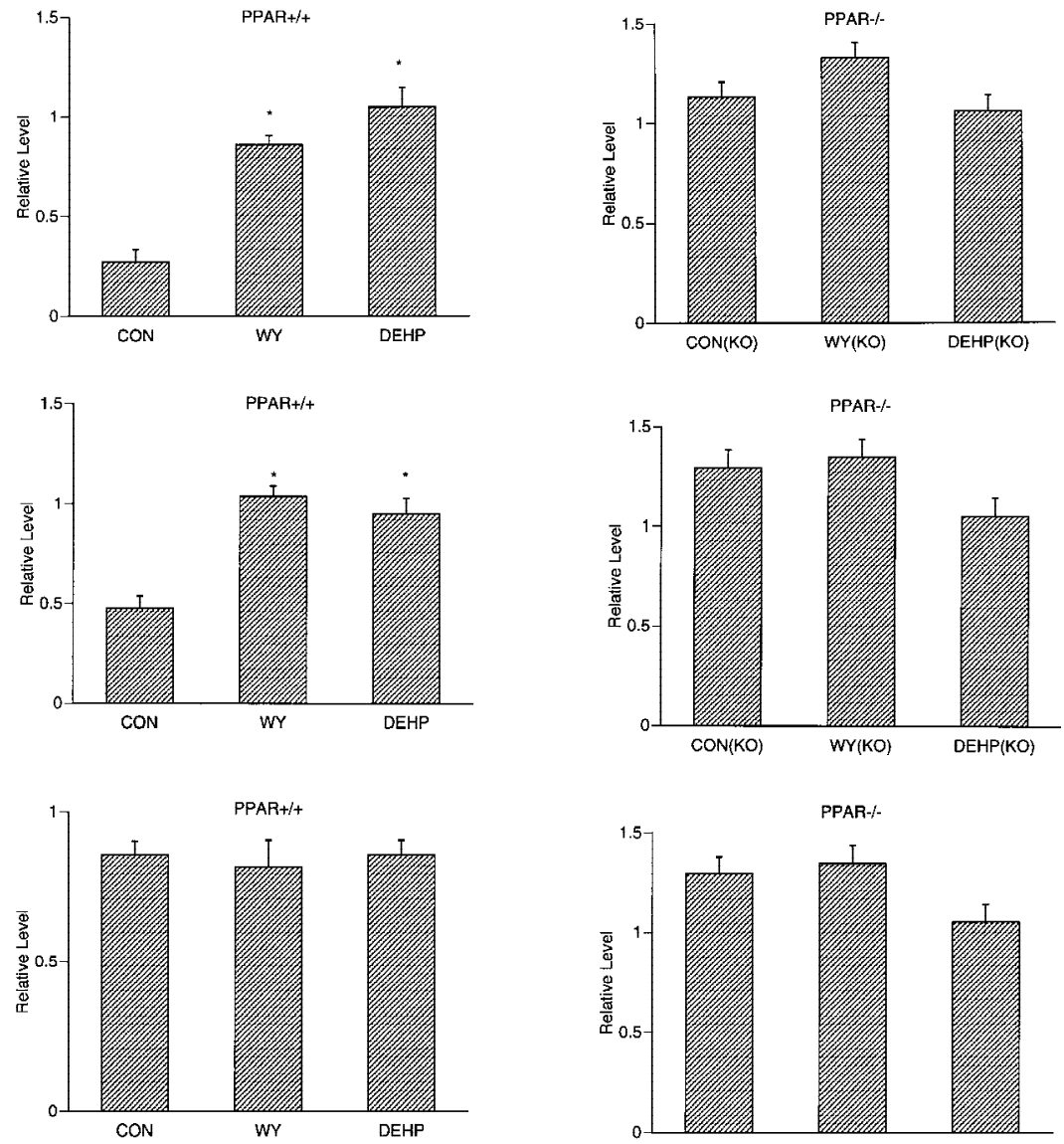

Figure 5 Regulation of $17 \beta$-HSD IV mRNA levels after PPC exposure in wild-type and PPAR $\alpha$-null mice. Northern blot analysis of $17 \beta$-HSD IV mRNA in liver (A, left-hand panel), kidney (B, left-hand panel), and testis (C, left-hand panel) from male SV129 wild-type (PPAR+/+) and SV129 PPAR $\alpha$-null mice (PPAR-/-) fed a control diet (Control), WY (0.1\%) or DEHP $(0 \cdot 6 \%)$ for three weeks. Total RNA samples were separated on formaldehyde-agarose gels, transferred to nylon membranes and probed with either the full-length rat $17 \beta$-HSD IV cDNA or a fragment of $\beta$-actin. The autoradiograms were denistometrically scanned and mouse $17 \beta$-HSD IV expression in liver, kidney and testis was normalized to $\beta$-actin expression. The histograms show the mean induction (mean \pm s.D.) in wild-type mice (middle panels) or PPAR $\alpha$-null mice (right-hand panels) from two or three different samples. ${ }^{*} P<0.05$ compared with control. KO, knock out.

observed after PPC exposure in wild-type mice or PPAR $\alpha$-null mice.

\section{Discussion}

The 17 $\beta$-hydroxysteroid dehydrogenase type IV was identified as a gene whose mRNA was elevated in the livers of rats after exposure to peroxisome proliferator chemicals (Corton et al. 1996). Despite their structural dissimilarity these chemicals elicit a common set of responses in rodents including peroxisome proliferation, increased hepatocyte proliferation and decreased apoptosis, alteration in fatty acid metabolism, and after long-term exposure, hepatocarcinogenesis (reviewed in Lapinskas \& Corton 1998). Treatment may also lead to alterations in endocrine function as changes in serum estrogen levels in both male and female rats have been observed after exposure to some PPC (summarized in Corton et al. 1997). In an effort to characterize the tissue-specificity and mechanism of the PPC-responsiveness of HSD family members, we examined expression in different tissues of rats and mice after exposure to diverse PPC. The results led to three main conclusions.

First, the induction of the $17 \beta-\mathrm{HSD}$ mRNA by PPC was restricted to the type IV gene and only in those tissues which significantly respond to the enzyme inductive effects of PPC. Alteration in 17 $\beta$-HSD I, II or III mRNA levels was not observed in a number of tissues important in sex hormone synthesis or degradation. The strongest induction of $17 \beta-$ HSD IV was observed in rat and mouse liver, with moderate induction in the kidney. Induction of $17 \beta-H S D$ IV in the liver was not limited to one subgroup of PPC but to all PPC tested in this study including 

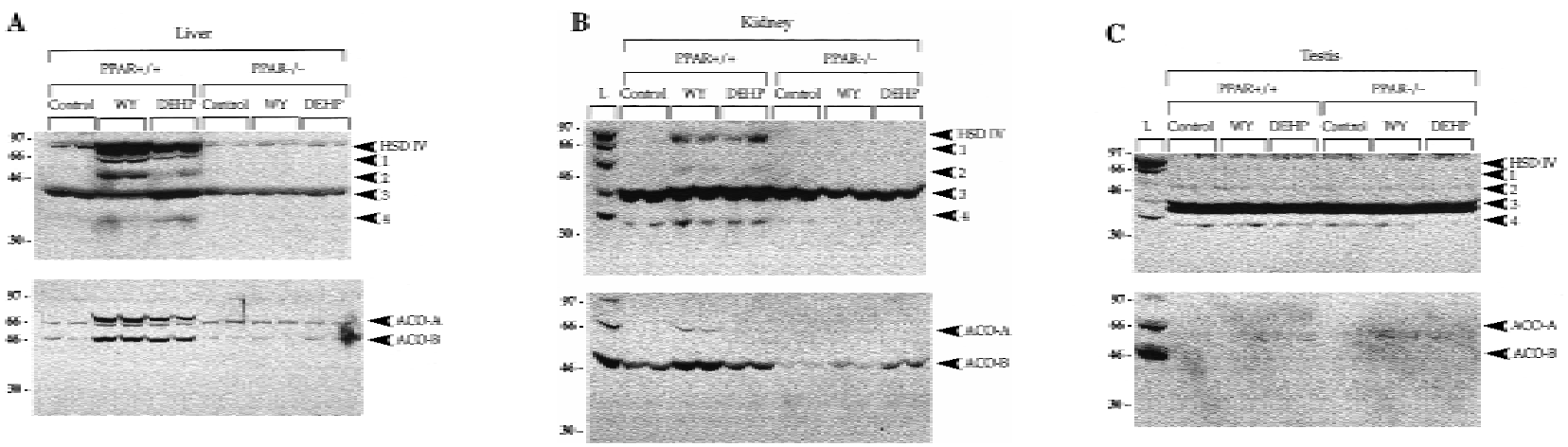

Figure 6 Regulation of $17 \beta$-HSD IV protein levels after PPC exposure in wild-type and PPAR $\alpha$-null mice. Western blot analysis of $17 \beta$-HSD IV protein levels in whole-cell extracts from livers (A), kidneys (B) and testis (C) of mice described in the legend to Fig. 5. Protein extracts $(100 \mu \mathrm{g})$ were separated by $12 \cdot 5 \%$ SDS-PAGE, transferred to nitrocellulose membranes and probed with antibodies against $17 \beta$-HSD IV or ACO. In (B) and (C), a liver protein extract from a rat treated with 8000 ppm GEM for 13 weeks was run as a control (L). 17 $\beta$-HSD IV, position of the full-length $80 \mathrm{kDa}$ rat $17 \beta-\mathrm{HSD}$ IV protein; 1-4, positions of immunoreactive proteins with molecular masses of $66,56,42$ and $32 \mathrm{kDa}$ respectively. Position of ACO forms $\mathrm{A}$ and $\mathrm{B}$ are indicated. The numbers on the left indicate the position of molecular mass markers $(\mathrm{kDa})$.

hypolipidemic drugs (WY, GEM and CA) and phthalate ester plasticizers (DBP and DEHP). In contrast, another group (Qin et al. 1997) found that CA had no effect on $17 \beta-H S D$ IV protein levels in liver. Although we could detect constitutive expression of the mRNA and/or protein in many other tissues including testes, heart, and adrenals in the absence of exposure, expression of $17 \beta-$ HSD IV could not be induced by PPC in these tissues even after long-term exposure to relatively high doses of PPC. This tissue-restricted pattern of PPC-inducibility of $17 \beta-H S D$ IV is identical to the inducibility of other peroxisomal genes/proteins which catalyze $\beta$-oxidation of fatty acids such as ACO, the multifunctional protein, and thiolase (Nemali et al. 1988). In our studies we detected induction of ACO in all tissues where $17 \beta-H S D$ IV was induced, although weak induction of ACO but not $17 \beta-H S D$ IV was also detected in adrenals and brown fat. Taken together, these results indicate that inducibility of $\beta$-oxidation genes and inducibility of $17 \beta-H S D$ IV share a common mechanism.

Secondly, we have shown that the induction of the $17 \beta-H S D$ IV mRNA and protein by PPC is mediated by a member of the nuclear receptor superfamily called PPAR $\alpha$. This receptor has been shown to mediate most, if not all, of the effects of PPC in the liver including enzyme induction, peroxisome proliferation (Lee et al. 1995), cell proliferation and carcinogenesis (Peters et al. 1997). PPCinduced increases in $17 \beta$-HSD IV levels were completely abolished in both livers and kidneys from mice which lack a functional PPAR $\alpha$. No induction of $17 \beta-H S D$ IV in heart (data not shown) or testis (Fig. 6C) was detected even though PPAR $\alpha$ and other PPAR isoforms which are activated by PPC are expressed in these tissues (Braissant et al. 1996). It is possible that PPAR $\alpha$, the preferential target of PPC action, is not expressed in these tissues to levels high enough to initiate induction or a mechanism is in place to block the ability of PPAR $\alpha$ to activate $17 \beta-H S D$ IV transcription. Our data also demonstrate that $17 \beta-\mathrm{HSD}$ IV is constitutively regulated in many tissues by a mechanism that does not involve PPAR $\alpha$ but could involve the $\operatorname{PPAR} \delta$ isoform which is broadly expressed or the PPAR $\gamma$ isoform which is mainly expressed in adipose tissue including brown fat (Braissant et al. 1996). Because PPAR $\alpha$ is also activated by endogenous prostaglandins, 8Shydroxyecosatetraenoic acid and leukotriene $\mathrm{B}_{4}$ (summarized in Lapinskas \& Corton 1998), 17 $\beta$-HSD IV levels could be augmented under physiological conditions in which these eicosanoids are elevated.

Thirdly, we have shown that rat and mouse tissues express a number of proteins with conserved sizes which are immunoreactive with the anti-17 $\beta$-HSD IV antibody and most likely result from proteolytic processing of the full-length $80 \mathrm{kDa}$ protein for the following reasons. (1) The fragments $(66,56,42$ and $32 \mathrm{kDa})$ were detected by two different antibodies raised to $17 \beta-H S D$ IV and thus are unlikely to result from recognition of an epitope in an unrelated protein. (2) The abundance of the fragments parallels the abundance of the full-length protein. GEM strongly induces the full-length protein as well as the fragments. WY or DBP only weakly induce the full-length protein and the fragments. (3) Fragments of similar sizes with activities associated with $17 \beta$-HSD IV have been isolated by other groups (Adamski et al. 1992, Qin et al. 1997). Isolation and characterization of a $\sim 32 \mathrm{kDa}$ protein with 2-enoyl-CoA hydratase 2 activity from rat liver led to the cloning of the full-length rat 17 $\beta-H S D$ IV (Qin et al. 1997). Additional fragments of 66 and $46 \mathrm{kDa}$ identified by Western analysis using polyclonal antibodies to the hydratase- 2 domain were also identified in rat liver in this study. In pigs, a $32 \mathrm{kDa}$ protein was isolated with dehydrogenase activity (Adamski et al. 1992). Our data support a model in which the full-length $80 \mathrm{kDa} 17 \beta-\mathrm{HSD}$ IV is 
induced by PPC exposure in responsive tissues, followed by immediate limited proteolysis to defined fragments. In the absence of PPC exposure and consistent with the constitutive expression of $17 \beta-H S D$ IV mRNA, constitutive expression of the $42 \mathrm{kDa}$ fragment is found in rat kidneys and adrenals and in mouse livers, kidneys, and testes.

Preliminary evidence indicates that the full-length $17 \beta$ HSD IV from rats is proteolytically processed in situ between residues 312-326 (Qin et al. 1997) at a site similar to that first observed in the pig enzyme (Leenders et al. 1994). Cleavage of the rat protein at this site would result in a $32 \mathrm{kDa} \mathrm{N}$-terminal fragment and a C-terminal fragment with a size almost identical to the $46 \mathrm{kDa}$ fragment observed earlier in liver extracts and isolated peroxisomes (Dieuaide-Noubhani et al. 1997b, Qin et al. 1997) and very similar in size to the $42 \mathrm{kDa}$ fragment observed in our studies. This simplified proteolytic processing scheme, however, does not explain all of the fragments observed in our study as we also observe 66 and $56 \mathrm{kDa}$ fragments only after PPC treatment in liver and kidney and a constitutively expressed $38 \mathrm{kDa}$ protein in mouse testis. The proteolysis of $17 \beta-\mathrm{HSD}$ IV in many tissues where there is constitutive expression must be rapid since the $42 \mathrm{kDa}$ fragment, but little, if any, of the full-length form is detected in these tissues. Additional processing pathways important in generation of the other fragments awaits characterization.

Based on an analysis of the functional properties of individually expressed putative domains of $17 \beta-$ HSD IV, Leenders et al. (1996) concluded that individual functions are encoded by different domains of the protein. The N-terminal $32 \mathrm{kDa}$ fragment (amino acids $1-323$ ) is able to perform the dehydrogenase reaction not only with steroids at the C17 position but also with 3-hydroxyacylCoA. The central portion of the protein, amino acids 324-596 catalyzes the 2-enoyl-acyl-CoA hydratase reaction. The C-terminal amino acids 597-737 are homologous to sterol carrier protein 2 and facilitate the transfer of 7-dehydrocholesterol and phosphatidylcholine between membranes in vitro. Although the origin of the fragments that have $17 \beta-H S D$ IV immunoreactivity identified in our studies and those of others has not been defined, it is likely that tissue-specific expression of the fragments will give a characteristic profile of activities important in the metabolism of fatty acids and steroids.

Porcine (Adamski et al. 1992) and human (Adamski et al. 1995) $17 \beta-H S D$ IV principally catalyze the oxidation of the most active estrogen, estradiol to the less active estrogen, estrone. A physiological consequence of overexpression of $17 \beta-$ HSD IV by PPC would be a decrease in circulating estradiol levels in responsive rodent species. Decreases in serum estradiol levels have not been observed in male rats but rather, under some but not all conditions of PPC exposure, an increase in liver aromatase activity has been shown to lead to increased serum estradiol levels
(Biegel et al. 1995). On the other hand, treatment of female rats with the PPC, DEHP, results in a dramatic drop of serum estradiol levels (Davis et al. 1994a). This suppression of estradiol levels leads to secondarily increased serum follicle-stimulating hormone levels, an absence of luteinizing hormone surges necessary for ovulation and results in polycystic ovaries in rats (Davis et al. 1994a). In addition to increased expression of $17 \beta-\mathrm{HSD}$ IV in liver and kidney, the decrease in serum estradiol levels could also be due to lowered secretion of estradiol from preovulatory granulosa cells (Davis et al. 1994b). Mouse granulosa cells have been shown to express the $17 \beta$-HSD IV protein (Normand et al. 1995), although the effect of PPC exposure on increased levels of $17 \beta$-HSD IV protein is not known in these cells.

In summary, we show $17 \beta-$ HSD IV is regulated by at least two different mechanisms: (1) a PPC-inducible mechanism requiring PPAR $\alpha$ in a limited number of tissues and (2) a PPAR $\alpha$-independent mechanism in many tissues important for constitutive expression. The overexpression of $17 \beta-H S D$ IV by PPC in liver and kidney could lead to altered intracellular and extracellular estrogen levels and consequently, disrupt normal homeostasis of estrogen-dependent functions.

\section{Acknowledgements}

We thank Dr Frank Gonzalez for providing parental SV129 wild-type and PPAR $\alpha$-null mice, Drs Stefan Alexson, Jerzy Adamski, and Takashi Hashimoto for antibodies, Drs Paul Baker and Hellevi Peltoketo for plasmids, and Drs Madhabananda Sar and Kevin Gaido for reviewing the manuscript. We also thank Cynthia Swanson and Chris Rini for technical assistance and Sadie Leak and Linda Smith for preparation of the manuscript.

\section{References}

Adamski J, Husen B, Marks F \& Jungblut PW 1992 Purification and properties of oestradiol $17 \beta$-dehydrogenase extracted from cytoplasmic vesicles of porcine endometrial cells. Biochemical Journal 288 375-381.

Adamski J, Normand T, Leenders F, Monte D, Begue A, Stehelin D, Jungblut PW \& Launoit YD 1995 Molecular cloning of a novel widely expressed human $80-\mathrm{kDa} 17 \beta$-hydroxysteroid dehydrogenase IV. Biochemical Journal 311 437-443.

Akinola LA, Poutanen M \& Vihko R 1996 Cloning of rat $17 \beta$-hydroxysteroid dehydrogenase type 2 and characterization of tissue distribution and catalytic activity of rat type 1 and type 2 enzymes. Endocrinology 137 1572-1579.

Andersson S \& Moghrabi N 1997 Physiology and molecular genetics of $17 \beta$-hydroxysteroid dehydrogenases. Steroids 62 143-147.

Biegel LB, Liu RCM, Hurtt ME \& Cook JC 1995 Effects of ammonium perfluorooctanoate on Leydig cell function: in vitro, in vivo, and ex vivo studies. Toxicology and Applied Pharmacology 134 $18-25$.

Biswas MG \& Russell DW 1997 Expression cloning and characterization of oxidative $17 \beta$ - and $3 \alpha$-hydroxysteroid dehydrogenases from rat and human prostate. Journal of Biological Chemistry 272 15959-15966. 
Braissant O, Foufelle F, Scotto C, Dauça M \& Wahli W 1996 Differential expression of peroxisome proliferator-activated receptors: tissue distribution of PPAR $\alpha, \beta$ and $\gamma$ in the adult rat. Endocrinology 137 354-366.

Carstensen JF, Tesdorpf JG, Kaufmann M, Markus MM, Husen B, Leenders F, Jakob F, de Launoit Y \& Adamski J 1996 Characterization of $17 \beta$-hydroxysteroid dehydrogenase IV. Journal of Endocrinology $150 \mathrm{~S} 3-\mathrm{S} 12$.

Casey ML, MacDonald PC \& Andersson S 1994 17ß-Hydroxysteroid dehydrogenase type 2: chromosomal assignment and progestin regulation of gene expression in human endometrium. Journal of Clinical Investigation 94 2135-2141.

Chen J, Nikolova-Karakashian M, Merrill AH Jr \& Morgan ET 1995 Regulation of cytochrome P450 2C11 (CYP2C11) gene expression by interleukin-1, sphingomyelin hydrolysis, and ceramides in rat hepatocytes. Journal of Biological Chemistry 270 25233-25238.

Corton JC, Bocos C, Moreno ES, Merritt A, Marsman DS, Sausen PJ, Cattley RC \& Gustafsson J-A 1996 Rat $17 \beta$-hydroxysteroid dehydrogenase type IV is a novel peroxisome proliferator-inducible gene. Molecular Pharmacology 50 1157-1166.

Corton JC, Bocos C, Moreno ES, Merritt A, Cattley RC \& Gustafsson J-A 1997 Peroxisome proliferators alter the expression of estrogen-metabolizing enzymes. Biochimie 79 151-162.

Davis BJ, Maronpot RR \& Heindel JJ 1994a Di-(2-ethylhexyl)phthalate suppresses estradiol and ovulation in cycling rats. Toxicology and Applied Pharmacology 128 216-233.

Davis BJ, Weaver R, Gaines LJ \& Heindel JJ 19946 Mono(2-ethylhexyl)phthalate suppresses estradiol production independent of FSH-cAMP stimulation in rat granulosa cells. Toxicology and Applied Pharmacology 128 224-228.

Dieuaide-Noubhani M, Asselberghs S, Mannaerts GP \& Van Veldehoven PP 1997a Evidence that multifunctional protein 2, and not multifunctional protein 1 , is involved in the peroxisomal $\beta$-oxidation of pristanic acid. Biochemical Journal 325 367-373.

Dieuaide-Noubhani M, Novikov D, Vanderkerckhove J, Veldhoven PPV \& Mannaerts GP $1997 b$ Identification and characterization of the 2-enoyl-CoA hydratases involved in peroxisomal $\beta$-oxidation in rat liver. Biochemical Journal 321 253-259.

Geissler W, Davis DL, Wu L, Bradshaw KD, Patel S, Mendonca BB, Elliston KO, Wilson JD, Russell DW \& Andersson S 1994 Male pseudohermaphroditism caused by mutations of testicular 17ß-hydroxysteroid dehydrogenase type 3. Nature Genetics 7 34-39.

Ghersevich S, Nokelainen P, Poutanen M, Orava M, Autio-Harmainen H, Rajaniemi H \& Vihko R 1994 Rat 17 $\beta$-hydroxysteroid dehydrogenase type 1: primary structure and regulation of enzyme expression in rat ovary by diethylstilbestrol and gonadotropins in vivo. Endocrinology 135 1477-1487.

Goldsworthy SM, Goldsworthy TL, Sprankle CS \& Butterworth BE 1993 Variation in expression of genes used for normalization of Northern blots after induction of cell proliferation. Cell Proliferation 26 511-517.

Kedderis GL, Argenbright LS \& Miwa GT 1988 Studies with nitrogen-containing steroid and freshly isolated rat hepatocytes: role of cytochrome P-450 in detoxication. Toxicology and Applied Pharmacology 93 403-412.

Lapinskas PJ \& Corton JC 1998 Molecular mechanisms of hepatocarcinogenic peroxisome proliferators. In Molecular Biology Approaches to Toxicology. Eds A Puga \& KB Wallace. Washington, DC: Taylor and Francis (In Press).

Lee SS-T, Pineau T, Drago J, Lee EJ, Owens JW, Kroetz DL, Hermendez-Salguero PM, Westphal H \& Gonzalez FJ 1995 Targeted disruption of the $\alpha$ isoform of the peroxisome proliferatoractivated receptor gene in mice results in abolishment of the pleiotropic effects of peroxisome proliferators. Molecular and Cellular Biology 15 3012-3022.

Leenders F, Adamski J, Husen B, Thole HH \& Jungblut PW 1994 Molecular cloning and amino acid sequence of the porcine
$17 \beta$-estradiol dehydrogenase. European Journal of Biochemistry 222 221-227.

Leenders F, Tesdorpf JG, Markus M, Engel T, Seedorf U \& Adamski J 1996 Porcine 80-kDa protein reveals intrinsic $17 \beta$-hydroxysteroid dehydrogenase, fatty acyl-CoA-hydratase/dehydrogenase and sterol transfer activities. Journal of Biological Chemistry 271 $5438-5442$.

Luu-The V, Zhang Y, Poirier D \& Labrie F 1995 Characteristics of human types 1, 2 and 3 17 $\beta$-hydroxysteroid dehydrogenase activities: oxidation/reduction and inhibition. Journal of Steroid Biochemistry and Molecular Biology 55 581-587.

Markus M, Husen B, Leenders F, Jungblut PW, Hall PF \& Adamski J 1995 The organelles containing porcine $17 \beta$-estradiol dehydrogenase are peroxisomes. European Journal of Cellular Biology 68 263-267.

Martel C, Rheaume E, Takahashi M, Trudel C, Couet J, Luu-The V, Simard J \& Labrie F 1992 Distribution of $17 \beta$-hydroxysteroid dehydrogenase gene expression and activity in rat and in human tissues. Journal of Steroid Biochemistry and Molecular Biology $\mathbf{4 1}$ 587-603.

Mustonen MVJ, Poutanen MH, Isomaa VV, Vihko PT \& Vihko RK 1997 Cloning of mouse $17 \beta$-hydroxysteroid dehydrogenase type 2, and analysing expression of the mRNAs for types 1,2, 3, 4 and 5 in mouse embryos and adult tissues. Biochemical Journal $\mathbf{3 2 5}$ 199-205

Nemali MR, Usuda N, Reddy MK, Oyasu K, Hashimoto T, Osumi T, Rao MS \& Reddy JK 1988 Comparison of constitutive and inducible levels of expression of peroxisomal $\beta$-oxidation and catalase genes in liver and extrahepatic tissues of rats. Cancer Research 48 5316-5324.

Nokelaninen P, Puranen T, Peltoketo H, Orava M, Vihko P \& Vihko R 1996 Molecular cloning of mouse $17 \beta$-hydroxysteroid dehydrogenase type 1 and characterization of enzyme activity. European Journal of Biochemistry 236 482-490.

Normand T, Husen B, Leenders F, Pelczar H, Baert J-L, Begue A, Flourens A-C, Adamski J \& De Launoit Y 1995 Molecular characterization of mouse $17 \beta$-hydroxysteroid dehydrogenase IV. Journal of Steroid Biochemistry and Molecular Biology 55 541-548.

Peters JM, Cattley RC \& Gonzalez FJ 1997 Role of PPAR $\alpha$ in the mechanism of action of the nongenotoxic carcinogen and peroxisome proliferator WY-14,643. Carcinogenesis 18 2029-2033.

Qin Y-M, Poutanen MH, Helander HM, Kvist A-P, Sivari KM, Schmitz W, Conzelmann E, Hellman U \& Hiltunen JK 1997 Peroxisome multifunctional enzyme of $\beta$-oxidation metabolizing D-3-hydroxyacyl-CoA esters in rat liver: molecular cloning, expression and characterization. Biochemical Journal 321 21-28.

Rocos CL \& Ledwith BS 1997 Peroxisome proliferators activate extracellular signal-regulated kinases in immortalized mouse liver cells. Journal of Biological Chemistry 272 13452-13457.

Sha JA, Dudley K, Rajapaksha WRAKJS \& O'Shaughnessy PJ 1997 Sequence of mouse $17 \beta$-hydroxysteroid dehydrogenase type 3 cDNA and tissue distribution of type 1 and type 3 isoform mRNAs. Journal of Steroid Biochemistry and Molecular Biology $\mathbf{6 0}$ $19-24$.

Wilcke M \& Alexson SEH 1994 Characterization of acyl-CoA thioesterase activity in isolated rat liver peroxisome. Partial purification and characterization of a long-chain acyl-CoA thioesterase. European Journal of Biochemistry 222 803-811.

Zhang Y, Dufort I, Soucy P, Labrie F \& Luu-The V 1995 Cloning and expression of human type $\mathrm{V} 17 \beta$-hydroxysteroid dehydrogenase. 77th Annual Meeting of the Endocrine Society $\mathbf{6 2 2}$ P3-614.

Received 20 January 1998

Accepted 23 March 1998 